\title{
6 Planning and regulatory issues impacting sustainable property development
}

\author{
Pernille H. Christensen and Sarah L. Sayce
}

\subsection{Introduction}

The property development process actively contributes to the built environment in which we live. Planning and regulatory intervention are the public means of managing property development so that the resultant built environment is shaped by policy developed for protection and enhancement of the public interest, rather than mere market forces which promote private interests. They have the ability to speed up or to inhibit property development. To be effective, planners and policymakers must understand the property development process, the risks and rewards that drive property developers and investors, and the impact that planning instruments have on the decision-making process of property developers and investors. The International Society of City and Regional Planners (ISOCARP 2001) has identified five basic elements of a planning system:

- source(s) of power (for planning intervention), articulated through national, state, regional, local or equivalent levels of government and legislation;

- a balance of strategic policies underpinned by incentives to encourage preferred development, and controls to constrain undesirable impacts;

- regulation: the need for consent to carry out change;

- legal rights for public consultation, including rights to object to a plan or decision; and,

- financial arrangements for public infrastructure and for planning administration.

(ISOCARP 2001)

Globally, there have been many changes at each of the power levels of planning in an effort to acknowledge and accommodate the need to create more sustainable urban areas. This chapter highlights what is happening worldwide, sets out the rationale for the direction of policy travel changes and analyses how these changes impact the property development process and, in particular, how they can promote more sustainable developments. Whilst the very nature of planning is that it differs between geographic regions and countries, there are overarching principal issues that provide common threads; these are explored within the chapter so that readers are able to place the practice within their own jurisdiction within a wider context. There are three main instruments through which planning authorities can impact the development process; these include strategic or detailed development plans, development controls and incentives.

Development plans provide the context for control decisions by detailing strategies and principles for planning authorities to implement when managing land use, spatial planning, 


\section{Pernille H. Christensen and Sarah L. Sayce}

environmental and other development issues. Planning authorities also use development plans to indicate where they would like to encourage development (e.g. by identifying land for specific uses in some areas), direct development (e.g. allowing some development uses/scales in the CBD but not residential) or prevent development (e.g. by identifying park space). As such, development plans offer guidance for the property market, helping landowners, developers and investors better understand what type of property development is likely to be accepted on the land.

Development controls are the administrative mechanisms that enable planning authorities to make decisions related to specific development proposals. Often, the development controls offer additional details related to the type and location of development, design guidelines related to development (such as scale and appearance, and urban design principles) such as setbacks and sidewalks. Planning authorities are able to use development controls to uphold the development plan, but also to exercise discretion and offer exceptions to the plan. Likewise, landowners, developers and investors can utilise development controls in a community to challenge the strategies and principles of the local development plan.

Development incentives are tools utilised by planning authorities to help stimulate property development and investment within their communities. In many ways, development incentives may be the most effective instrument that planning authorities have at their disposal to promote sustainable property development. Among other things, development incentives can be used to promote and market specific areas within a city, to make land available for development, provide subsidies and/or streamline the approval process. Many cities, councils and organisations have commenced implementing sustainability initiatives, however, few are maximising engagement with their stakeholders on their initiatives. Community and stakeholder engagement is key in reaping the rewards from implementing sustainable projects, gaining stakeholder buy-in, motivating behaviour change and in ensuring that sustainability continues to remain a key strategic driver for change. The issue of community engagement is covered as a separate section.

This chapter will discuss each of the development plans, controls and incentives utilised by planners in Australia, the UK and the US in more detail. However, it should be noted that the scope of this topic and the relationship between development plans, controls, and incentives is too much to examine in detail in a single chapter. As such, the research as presented in this chapter identifies specific statutory plans and controls which have a higher degree of impact on sustainable property development applications, appeals and enforcement. In addition, development incentives, which have shown to have a positive impact on promoting sustainable property development, are also discussed. Lastly, a case study of the Bullitt Centre in Seattle, and the Living Building Ordinance, developed by the city of Seattle as a demonstration ordinance, that enabled the Bullitt Centre to achieve full Living Building Challenge certification.

\subsection{Global planning and policy trends impacting sustainable property development}

Historically, local planning laws in middle Europe were guided by sustainability concerns through the eighteenth century. Their approach centred around the land-use systems known as 'allmende' (German) and 'commons' (UK) (Bosselmann 2013). The underpinning concerns of allmende were governed by ethics different from those informing modern property rights. The human-nature relationship was one of stewardship in that land could only be owned in so far as it was managed in an ecologically sustainable manner. Humans 
were users of land; it was a privilege, not a right. Common interests of the community took preference over individual property rights, thereby resulting in the principle of optimisation over maximisation (Bosselmann 2013). However, over the course of the nineteenth century, public environmental law virtually disappeared in some parts of Europe.

The Industrial Revolution dramatically transformed the way land and other natural resources were utilised. This was seen in three aspects: 1) the pressures of population growth cause the agricultural system to expand beyond its natural boundaries; 2) there was a philosophical change which resulted in natural resource exploitation being favoured over ecological sustainability; and, 3) the use of fossil fuels replaced renewable resources as the main producers of energy. Public land law reflected this change in the modern economy; shortterm, free enterprise development became favoured over long-term, sustainable development. Private law and absolute property rights emerged as the reigning legal frameworks and largely ignored environmental protection and sustainability issues (Bosselmann 2013).

In many countries it was not until the mid-twentieth century that governments realised the need for environmental safeguards to protect natural resources. However, this was not the case in the UK which had introduced land-use planning provisions much earlier with the first specific planning act dating back to 1909 which outlawed back-to-back housing, and urban sprawl was effectively curtailed through the 1935 Control of Ribbon Development Act. By 1947 in the UK a comprehensive system of land-use controls, based on recognition of the needs to rebuild after the Second World War has laid out a combined tax/compensation regime to work alongside what was effectively a nationalisation of all rights to develop land. Whilst the tax regime was short-lived, the notion of development rights belonging to the state and administered by local authorities in the public interest has not been seriously challenged and laid down a fundamental framework within which subsequent moves towards recognition of sustainability concerns could become embedded. For a detailed examination of the role of planning see Rydin (2011).

In response to the environmental movement of the 1960s and 1970s, environmental monitoring and regulatory targets related to emissions and other pollutants began to be introduced, and clean-up operations of brownfield sites began to be required (Christensen 2012; Simons et al. 2001). Although similar legislative efforts have occurred since then, Bosselmann notes that even until today, 'environmental law has remained a poor cousin of property and commercial law, only able to promote "insufficient measures at the periphery"” (Bosselmann 1995: 10, 2013: 16). Many of the important land-use legal cases and regulations have been more so related to property rights, in that they merely added social (e.g. low-cost housing requirements in Southern Burlington Country NAACP vs. Mt. Laurel Township, 336 A2d 713, New Jersey, 1975) or environmental duties (e.g. the Comprehensive environmental Response, Compensation, and Liability Act (CERCLA), 1980, US - commonly known as Superfund) to otherwise unrestricted property rights.

In recent decades, the need to combat environmental degradation caused by the depletion of natural resources, pollution, global warming and the growing urban sprawl in the outskirts of some cities has resulted in environmental issues becoming national priorities in many countries as they prepare for further population growth (Pitts 2004). Even businesses are expressing concern over the economic impacts of sprawl (Ohm 2000). Whilst sprawl has been a major issue within the US, in the UK the green belts have proved on balance to be highly successful as a containment strategy (Amati et al. 2006), although this has not been without its challenges (Amati 2012). Green Belt policies are not just a UK phenomenon; they have been utilised in countries as diverse as for example China (Zhao 2011) and Estonia (Kepp 2011). Apart from the use of tight policies such as green 


\section{Pernille H. Christensen and Sarah L. Sayce}

belts, smart growth, compact cities, new urbanism and liveable communities have emerged as some of the potential alternative policy solutions to sprawl. More recently, in some areas, such as the US, the transformation beyond an industrial economy has presented the pressure of de-population with its attendant social issues reflected in the condition and economic sustainability of real estate leading to calls for increased green infrastructure and community engagement. (Schilling and Logan 2008).

Thus, planning strategies influence development plans and controls (e.g. form- and performance-based codes) as well as the types of incentives offered for sustainable property development (e.g. streamlined approval for 'green' property development; match to tax regimes). As such, discussions related to the economic viability, character of place and actual level of sustainability of these alternative planning strategies have entered the debate. It should be noted, that 'green', 'environmental' and 'sustainable' development are often used interchangeably within these and other urban planning strategies and the instruments will which plan, control and incentivise them. This chapter does not make judgments about the level of sustainability of the various instruments, but focuses on the strategies they take to encourage and promote sustainable property development in their communities.

\subsection{Development plans and controls}

There are normally two key stages in the urban planning process: 1) forward planning which defines strategic objectives and policies to achieve them, and 2) development control or management, which assesses development proposals against planning policies. Some countries place greater emphasis on one stage of the planning process than the other. Although strategic planning and development assessment should in theory be two sides of a single coin, in practice there is often a greater emphasis placed on development control/ management in part because the resources and expertise of many planning authorities are limited leading to an incomplete policy framework. In other instances, it can be caused by the locus of decision-making lying in the hands of elected lay committee members, rather than planning professionals. It could also be argued that it is this lack of emphasis on strategic planning which has caused some of the urban challenges related to sustainability which many of our cities face today.

To legitimise the development planning and control functions of a planning system the relevant source of power (see ISOCARP above) must be identified through legislation or, in some cases, from several pieces of legislation (Gurran 2011). Different countries assign the source of power either in a top-down or a bottom-up manner. The source of power assigned to a given planning legislation is often tied to the government's philosophy related to property rights (Bosselmann 2013).

For example, Australia and the United States have limited national involvement in planning and policy development, and have a strong emphasis on individual property rights. In these countries, states are responsible for enacting their own legislation related to land-use planning systems while local governments are responsible for the detailed responsibilities related to preparing plans and assessing property developments. In contrast, the planning system in the United Kingdom assigns responsibility to the local planning authorities for enforcing the plan-making and development assessment policies outlined at the national planning policy level, although there have been recent moves to reduce the types of development requiring explicit consent.

Planning controls support development plans by explaining the standards and restrictions for a new development in more detail. Controls can be created for multiple locations and 
scales (e.g. suburb, street or single lot), types of development (e.g. residential, commercial or industrial) or for particular components of the development (e.g. provision of car parking, control of storm water).

Some planning authorities argue that stringent development plans and controls cannot be justified in areas of economic decline (Hall 2011). Hall's response offers clear direction to tentative planning authorities and offers a case for implementing planning designs and policy. He explains that areas experiencing economic decline should not shy away from pressing developers to achieve high design standards as such profits are most often more profitable. Additionally, high quality developments also add value by promoting regeneration in the community. He notes that 'Reluctance on behalf of both parties to pursue higher standards is more in the mind than in the pocket' (Hall 2011: 90-91).

In the sections that follow, the development plans and controls for Australia, the UK and the US will be discussed, and the impacts of each planning system on sustainable property development will be highlighted. Table 6.1 shows an overview of the planning instruments for each country. This will be followed by a discussion of the development incentives used by planning authorities to promote sustainable development.

\subsubsection{Australia}

The national government in Australia has minimal impact on the planning process at the state and local levels. There are two exceptions. The Environment Protection and Biodiversity Conservation Act 1999 establishes a framework for assessing impacts of urban planning decisions on, among other considerations, threatened species, World Heritage and National Heritage sites. The national urban policy, released by the Minister of Infrastructure in May 2011, presents a national approach to urban development and offers overarching goals for the nation's cities as well as an approach for addressing the inherent challenges Australian cities must address to become more productive, sustainable and liveable. It identifies 14 key Australian government initiatives and sets short-, medium- and long-term targets and goals for each initiative (DIT 2011).

At the state/territory level, each of the six states and two territories in Australia have their own planning laws and procedures resulting in different systems for land-use management and planning. As such, there is no unified planning system for Australia. Although there are many similarities in the overall approach, each state has their own planning system which operates independently of other states. In order to discuss state and local-level planning systems of Australia in more detail, the discussion below has focused on the planning system in New South Wales. Gurran (2011) offers an excellent assessment of the breadth of issues and challenges related to the Australian urban land-use planning principles, systems and practices.

The primary planning instruments used in New South Wales are the Environment Planning and Assessment Act (EP\&A Act) of 1979 and the Environmental Planning and Assessment Regulation 2000. The plan-making system in NSW is explained in Part 3 of the EP\&A Act, while the majority of development proposals in New South Wales are assessed under Part 4. It should be noted that the EP\&A Act includes a revision for the public to participate in planning decisions impacting the future development of their communities. In addition, environmental planning instruments (SEPPs and LEPs, discussed below) are described as 'legal documents that regulate land use and development' (NSW 2014a).

In New South Wales (NSW) Local Environmental Plans (LEPs) guide planning decisions for local government areas. Area councils use zoning and development controls to regulate 
130 Pernille H. Christensen and Sarah L. Sayce

Table 6.1 Planning instruments

\begin{tabular}{|c|c|c|c|}
\hline & Australia & United Kingdom & United States \\
\hline Local & $\begin{array}{l}\text { Standard instrument local } \\
\text { environmental plan } \\
\text { Development control plan } \\
\text { Local planning study }\end{array}$ & $\begin{array}{l}\text { Local development plans } \\
\text { Supplemental planning } \\
\text { documents such as site } \\
\text { specific/area action plans } \\
\text { Adopted proposals map } \\
\text { Simplified planning zones }\end{array}$ & $\begin{array}{l}\text { Comprehensive plan } \\
\text { Zoning plan } \\
\text { Land use plan } \\
\text { Design guidelines }\end{array}$ \\
\hline Regional & $\begin{array}{l}\text { Now governed at the state } \\
\text { level }\end{array}$ & & $\begin{array}{l}\text { Not enforceable; local } \\
\text { planning authorities sign } \\
\text { voluntary agreements to } \\
\text { accomplish regional goals }\end{array}$ \\
\hline \multirow[t]{2}{*}{ State } & NSW & $\mathrm{N} / \mathrm{A}$ & \\
\hline & $\begin{array}{l}\text { Environmental Planning } \\
\text { and Assessment Act } 1979 \\
\text { Environmental Planning } \\
\text { and Assessment Regulation } \\
2000 \\
\text { State Environmental } \\
\text { Planning Policy (SEPPs) } \\
\text { Affordable Rental Housing } \\
\text { Policy }\end{array}$ & & $\begin{array}{l}\text { Set local planning } \\
\text { requirements (e.g. } \\
\text { comprehensive plan } \\
\text { requirements in OR and } \\
\text { WI) }\end{array}$ \\
\hline National & $\begin{array}{l}\text { Environment Protection } \\
\text { and Biodiversity } \\
\text { Conservation Act } 1999 \\
\text { National Urban Policy, } \\
2011\end{array}$ & $\begin{array}{l}\text { Planning Policy Acts } \\
\text { (e.g. Town and Country } \\
\text { Planning Act 1990; } \\
\text { Planning Act 2008; } \\
\text { Localism Act, 2011; } \\
\text { Growth and Infrastructure } \\
\text { Act, 2013) } \\
\text { National Planning Policy } \\
\text { Framework (NPPF), } 2012 \\
\text { Planning Policy Guidance } \\
\text { (currently under revision) }\end{array}$ & $\begin{array}{l}\text { CERCLA, } 1980 \\
\text { Standard State Zoning } \\
\text { Enabling Act, } 1924\end{array}$ \\
\hline
\end{tabular}

how land is used. Development Controls Plans (DCPs) supplement the LEP and provide specific, comprehensive requirements for types and locations of future development or locations. 'LEPs are the primary planning tool to shape the future of communities and also oversee the estimated $\$ 20$ billion worth of local [property] development that is determined each year' (NSW 2014b).

Most property development proposals in NSW require lodgement of a development application with the local council. As noted above, the EP\&A Act allows for public participation in decision-making related to future development. As such, depending on local council policy, the council will exhibit the development application and accept public comments before making a decision on the development application (DA). Figure 6.2 illustrates the development application process for New South Wales under the Standard Instrument LEP Programme. Minor modifications may still apply in some communities.

However, some development may qualify for a fast-tracked review process for complying development (e.g. home extensions, shop fit-outs) if the development type is specifically covered in the local council or NSW state codes. In this case, the complying development must be certified within ten days. Large developments also have the ability to by-pass local 


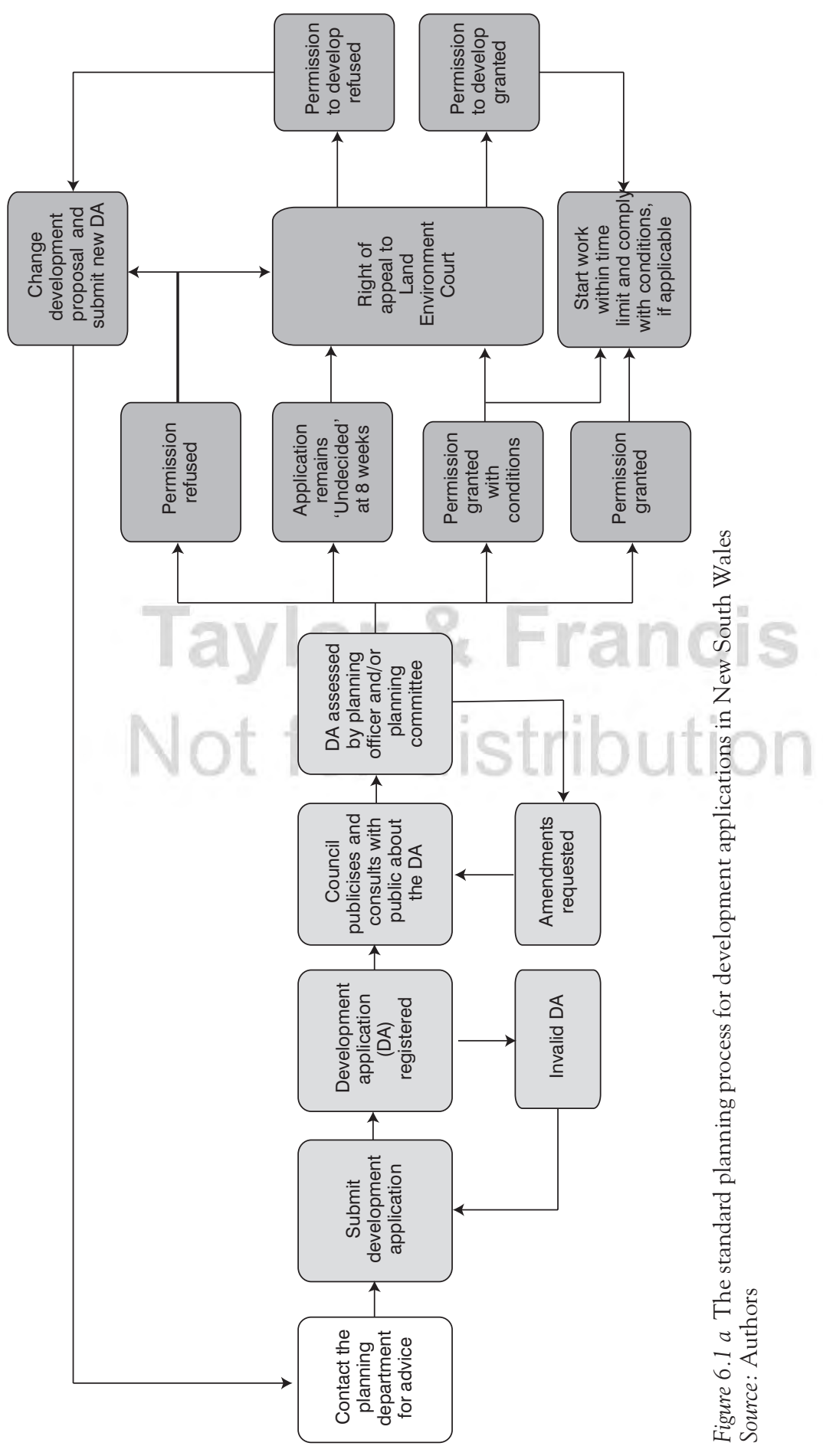




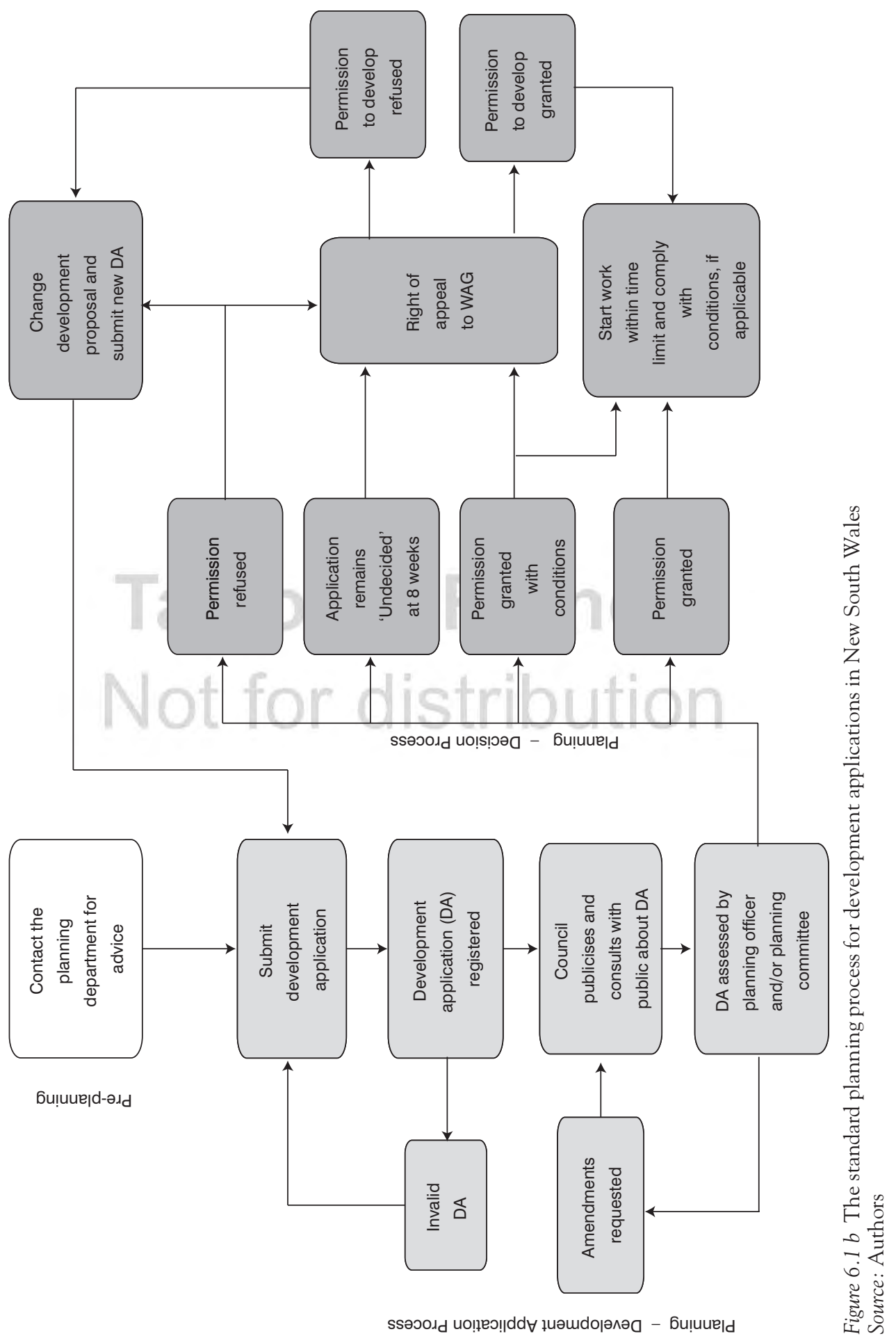


councils if they meet the requirements to be a state significant development (SSD). These developments have a certain capital investment value (CIV), are over a certain size, are located in a sensitive environmental area or in a precinct identified as important by the NSW government. The requirements for developments and sites to qualify for SSD status are found in Schedules 1 and 2 of the State and Regional Development SEPP. Alternatively, the Minister for Planning can declare a project as a SSD after consulting with the Planning Assessment Commission (PAC) on the state/regional significance of the development.

For development applications that are denied or approved with conditions, property developers have the option to appeal against the council's decision in the Land and Environment Court (LEC). The LEC was established by the Land and Environment Court Act 1979 as part of the EP\&A Act and as such deals with issues related to public law (i.e. citizens protecting their rights against the government). The court hears both merit and judicial appeals. A merit appeal involves examination and assessment of development application. For planning and building merit appeals related to Class 1 (environmental planning and protection appeals), Class 2 (local government and miscellaneous appeals), or Class 3 (land tenure, valuation, rating compensation) the court examines the development application afresh, de novo, rather than reviewing the council's decision. In such cases, the court is concerned with, as a matter of merit, the proposed development is 'good' or 'bad'. In contrast, a judicial review by the court only determines whether the council's decision was made in accordance with the law and is legally valid.

In 2006, The Standard Instrument LEP (SILEP) Programme was rolled out by the New South Wales government in an effort to create a standardised format and content for LEPs. The aim of the programme was to simplify and streamline development plan and control formats so that they might be more easily understood by planners, property developers and investors, and community members. Prior to this initiative, 'there were approximately 5,500 local planning instruments across the State, containing some 3,100 different land-use zones and 1,700 landuse definitions' (NSW 2014b). With such diversity, it is easy to understand NSW's aim of reducing this complexity to a single LEP used by all local government areas. Furthermore, the SILEP Programme standardises the language of the development plans by providing a standard suite of 35 land-use zones and approximately 250 land-use definitions (NSW 2014b). However, even local government areas who have adopted the SILEP still have additional planning instruments, for example. The following additional planning instruments apply to property development within the city of Sydney local area: Sydney Local Environmental Plan 2012, Sydney Local Environmental Plan 2005 (applies to the Frasers Broadway, the former Carlton and United Breweries site only; this will remain active until the completion of the Central Park development, which is currently o-going at the time of writing).

For those engaged with property development, the implementation of the Standard Instrument LEP Programme enables more efficient decisions to be made related to the planning process as local development plans are more easily assessed for content related to land use and planning requirements and exclusions. Key outcomes of implementing the Standard Instrument LEP Programme include:

- a consistent way of reflecting recent strategic land-use planning undertaken by councils and the NSW government;

- provision of an adequate supply of land for housing and employment;

- effective management of natural, environmental and cultural resources.

(NSW, 2014b) 


\section{Pernille H. Christensen and Sarah L. Sayce}

To further simplify the state's planning system, Regional Environmental Plans (REPs) were eliminated from the hierarchy of environmental planning instruments in NSW in July 2009. All existing REPs are now deemed State Environmental Planning Policies (SEPPs). SEPPs deal with issues significant to each individual state within Australia. Generally, SEPPs are created by the Governor upon the recommendation of the Minister for Planning and his team. Before being finalised as a legal document, SEPPs are first publicly exhibited in draft form for public feedback. During this time, community members, including property developers, are encouraged to submit letters of response to the government related to the proposed planning policy. This could change, however, if the new Planning Bill gets passed into law.

New South Wales has been undergoing the community engagement process since its review of the EP\&A Act by an independent review board was completed in 2011. The green paper, a new planning system for NSW was exhibited for public feedback in July 2012. In response to public feedback the white paper and associated draft planning legislation was created and exhibited for public feedback from April-June 2013. At the time of this writing, the proposed Planning Bill has been deferred by the Lower House (28 November 2013). Among the concerns of Lower House representatives are the change in structure of community consultation and the lack of emphasis on sustainable property development. The Planning Bill as written at the time of this writing emphasises community involvement early in the planning process, during the development of the Local Environmental Plan, rather than at the development approval stage, as is currently available. This would enable compliant development applications to be streamlined without input from community members. This has raised considerable debate in the media and concerns about the Planning Bill being 'pro-developer' and excluding community members from the decision-making process. On the other side of the debate are governmental officials supporting the bill. They highlight how this method of community consultation enables community members to influence the LEP which oversees the enforcement of requirements for development applications, and that compliant development should therefore be something community members would support. By streamlining development approvals, communities are more apt to attract new development and investment. A summary list of New South Wales SEPPS and regional planning policies can be found at: www.legislation.nsw.gov.au.

\subsubsection{United Kingdom}

In contrast to the Australian and American planning systems, the UK's current planning system takes a top-down source of authority approach, but with significant local variation still permitted, due to an increasing emphasis on community engagement (for a discussion see Holam and Rydin 2013). Planning in the UK has a long history, as outlined above and the introduction of a country-wide approach through a unified system in 1947 (Town and Country Planning Act (TPCA) 1947) was one of the earliest comprehensive approaches to land-use planning to be introduced anywhere in the world. It is controlled both through legislation and policy instruments and in recent years the notion of sustainable development has been placed at the heart of policy and statutory developments.

\subsubsection{The policy framework}

From the early days of comprehensive planning systems, there has existed a tiered policy system combined with development control (now called management). The policy 
environment requires local authorities to produce strategic documents which require consultation and national approval. The system by which policy has been set and plans produced has varied over time, normally being a two-tier system, sometimes three tier. In creating plans at the local level, the influence of central government has waxed and waned depending on the government of the day. In recent years it has become increasingly centralised as there have been moves from central 'guidance' notes to policy 'statements'.

However since 2011, with the enactment of the Localism Act, there has been a complete reform of the UK policy environment. Now, in terms of both setting out the government's intent for planning and their articulation of their understanding of sustainable development, the National Planning Policy Framework (NPPF) published in 2012 (CLG 2012) is the key controlling document. This sets out specifically that 'the purpose of the planning system is to contribute to the achievement of sustainable development' (NPPF: 3). When it was introduced it produced controversy as it also states that development means growth, which was argued by some to be a developer's charter which would damage rural interests (Brearley 2012). The NPPF provides the framework of principles within which all local planning authorities are charged with developing their own local plans and supplementary documents. At first reading, the principles are ones which promote sustainability, for example, the protection of the natural environment and heritage assets, the promotion of good design and the requirement that planning should assist in the moves to a low carbon economy. Where it has been seen as more difficult in sustainability terms is the presumption in favour of granting consent for development that is 'sustainable'. This places pressure on the interpretation of just what is or is not sustainable. Whilst the document is very clear that sustainable development embraces economic, social and environmental criteria, in practice there is a danger that the need to create job opportunities and increase the old and insufficient housing stock will outweigh environmental considerations, with planning authorities simply taking an accredited rating system attached to a building proposal (such as BREEAM) as sufficient evidence of the development being sustainable.

The introduction of the NPPF required all local planning authorities to revise their planning framework documents to incorporate the principles of the new framework; where this has not taken place there now exists the presumption that developments will be allowed unless there is good reason that they be rejected. Given the pressure that authorities have been under to do this in times of restricted budgets it is perhaps not surprising that as at the time of writing almost half of all local planning authorities have not achieved the required approved revised plans. This is disadvantageous in sustainability terms as the new plans all need to address specifically what is required in their areas to achieve for example biodiversity gains, reduced $\mathrm{CO}_{2}$ emissions, etc. One feature that is prevalent in most new documentation is a requirement to develop statutory code levels in terms of carbon emissions and reduction in energy use.

The other main UK planning policy initiative that is geared towards sustainability is the so-called shift from big government to big society; as movement set out through the Localism Act (2011) aimed at promoting the right of local people to shape the places in which they live and work. Whilst much of the Localism movement is geared towards local financing, it also embeds planning by giving greater rights to local communities to shape the plan process and determine the nature of developments. In some cases, it also gives such groups the right to develop without the need for express consent but whether these moves to increase democratisation will work is open to debate (see for example Allmendinger and Haughton 2014). 


\section{Pernille H. Christensen and Sarah L. Sayce}

Whilst UK planning is essential 'plan-led', in many areas there is a gap in up-to-date plans and decisions are therefore taken with reference only to outmoded plans and to the NPPF and to established case law. The actual development management process is set out in the Town and Country Planning Act (1990) as amended by the Planning and Compulsory Purchase Act (PCPA) 2004 and a raft of subsequent legislation including the Planning and Infrastructure Act 2013.

In summary, the UK's policy framework places high importance on sustainability principles lying at the heart of strategic planning; however progress towards embedding these principles at the local level is slower and, in any event, there is still such ambiguity over the interpretation of the principles (Paterson 2012) that it will take some time before it is seen to bring about the desired change in emphasis (Betts 2011).

\subsubsection{Development rights and managing community costs}

As stated above, under UK legislation, effectively all development rights are vested in the state with consent to undertake development being subject to consent (for a full explanation of the law see Duxbury 2012). When this principle was first introduced in 1947, a compensation system was set up to run alongside the act so that any development value pre-dating the planning system remained in the hands of the landowner, whilst any new development value arising was subject to taxation. In principle, this could be viewed as an equitable situation and a means of ensuring that value arising from community action (namely the grant of consent) was returned to the community by way of taxation. However, this system did not persist and within a few years development taxation was abolished and successive attempts to tax the land conversion process have been fraught with political difficulty and have largely proved unsuccessful. As at the time of writing, two systems to recoup for the community the value of planning and offset the negative externalities that result from development exist. These are planning obligations (or S.106 agreements as they are properly known) which require contributions on-site normally in the form of affordable housing or/and biodiversity and other environmental benefits and Community Infrastructure Levy (CIL) which is a discretionary local tax based on a floor area basis the proceeds of which are retained locally to supply the infrastructure demands occasioned by the development, such as clinics, parks and other facilities.

Both planning obligations and CIL are essentially measures which place additional costs on development and can act as a brake on demand for land by potentially decreasing profitability. On the other end of the scale, where authorities wish to drive up the speed of development take- up, incentives can be introduced such as Simplified Planning Zones which reduce the need for specific consent for development but do not provide ant financial assistance. Whilst some have been introduced in areas where there is perceived to be a local need to increase the rate of development, they are not common.

\subsubsection{The development application process}

Consent is required for any action that constitutes development as defined in S.55 of the 1990 Town and Country Planning Act. Development includes:

- building operations (e.g. structural alterations, construction, rebuilding, most demolition);

- material changes of use of land and buildings; 
- engineering operations (e.g. groundworks);

- mining operations;

- other operations normally undertaken by a person carrying out a business as a builder;

- subdivision of a building (including any part it) used as a dwelling for use as two or more separate dwellings.

However not all development requires explicit consent. First, some categories of work are specifically excluded from the definition, such as works to the interior of a non-listed building. Second, to reduce bureaucracy, by regulation (the General Permitted Development Order), many categories of small works are given a 'deemed' consent, which is capable of rescinding by the authority, albeit with possible compensation attached. Whilst the use of permitted development is important, both logistically and in common-sense terms, recent blanket consents including changes of use from offices to residential can have large impact on the cohesion and vitality of a central area and hence potentially negative social outcomes.

If the nature of the proposed scheme does not fall into one of the exclusions, it will require explicit consent. The development application process is managed by the local authority and Figure 6.3 below sets out in a flow diagram the normal process through which an application moves. Three important elements of the process from a sustainability perspective are:

- the pre-application process;

- the consultations required; and

- the documentation.

Following the implementation of the Planning Act 2008, there has been a requirement for all those seeking to make a planning application above prescribed threshold limits to enter into pre-application negotiations with the planning officers to establish the principles of the scheme. Whilst there was initial resistance by some developers to this process, which was viewed as an added expense and possible time delay (see the Killian and Pretty 2008), in reality this is not always the case and whilst it has been identified as a process capable of improvement it has been found to reduce the likelihood of conditions and appeals (Cambridge Centre for Housing and Planning Research 2014). It is therefore likely that the pre-application stage is one which, used constructively, can aid sustainable development. Although the 2008 Act envisaged only certain large applications requiring pre-application negotiations, the process is now spreading with the Localism Act empowering the use of pre-application advertisement if the authority so wishes. This is now being taken up by some authorities for small sensitive schemes such as solar arrays and wind turbines.

Once an application is lodged, depending on its size and level of contention (for example whether it is a departure from the local plan or is likely to have much opposition), there is normally a requirement to consult, both with statutory consultees, such as parish councils and utilities but also with the public. As in the US, there is a move towards genuine engagement with stakeholders as realisation has grown that to include the views of local inhabitants and businesses which the development will impact over a long term, is likely to lead to a more appropriate scheme. It is also likely to reduce opposition, speed up the process and reduce the need to appeal against any conditions or indeed receive a refusal. Again the consultation process offers the opportunity for sustainability features to be more carefully considered and appropriately incorporated. 


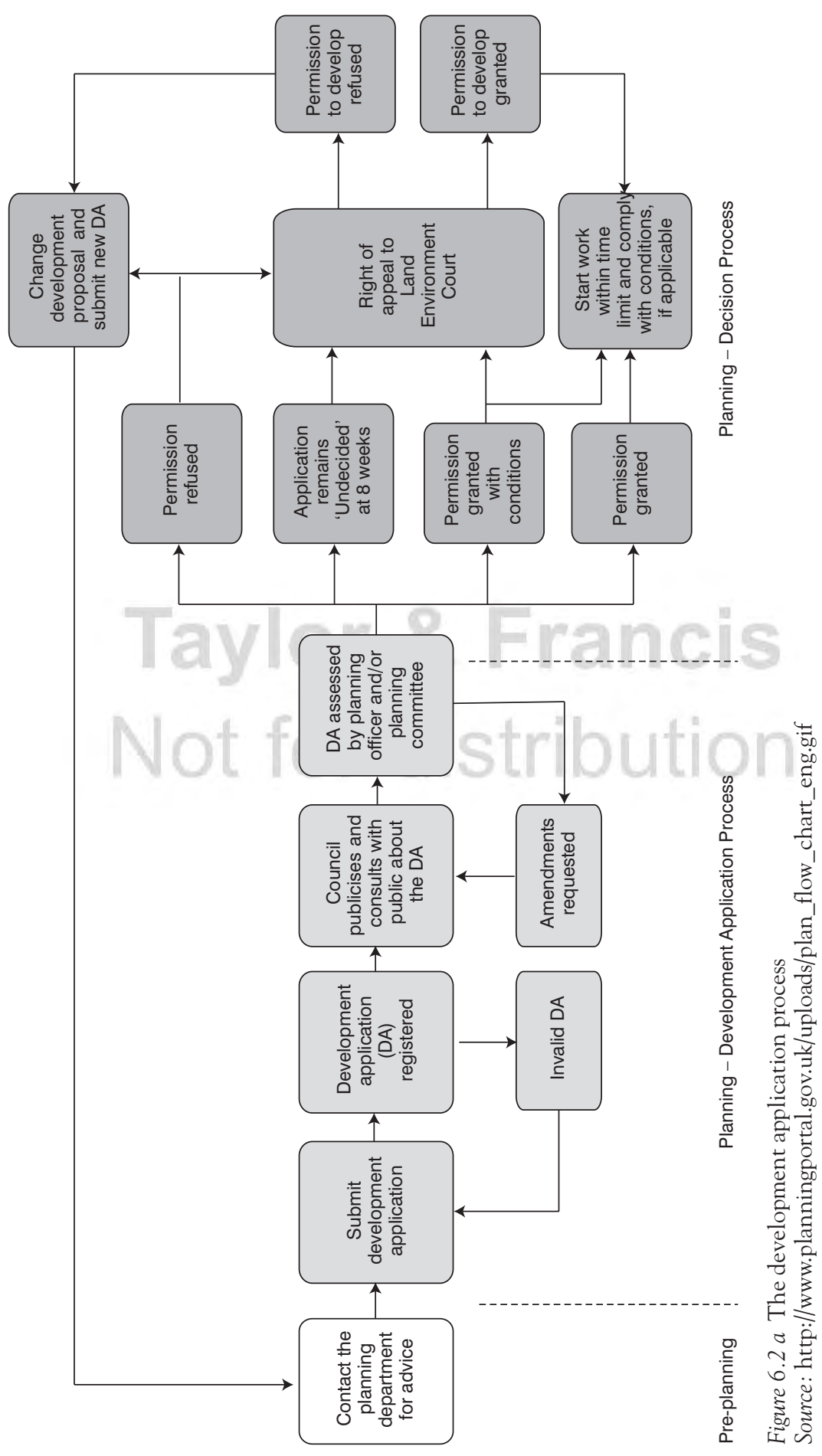




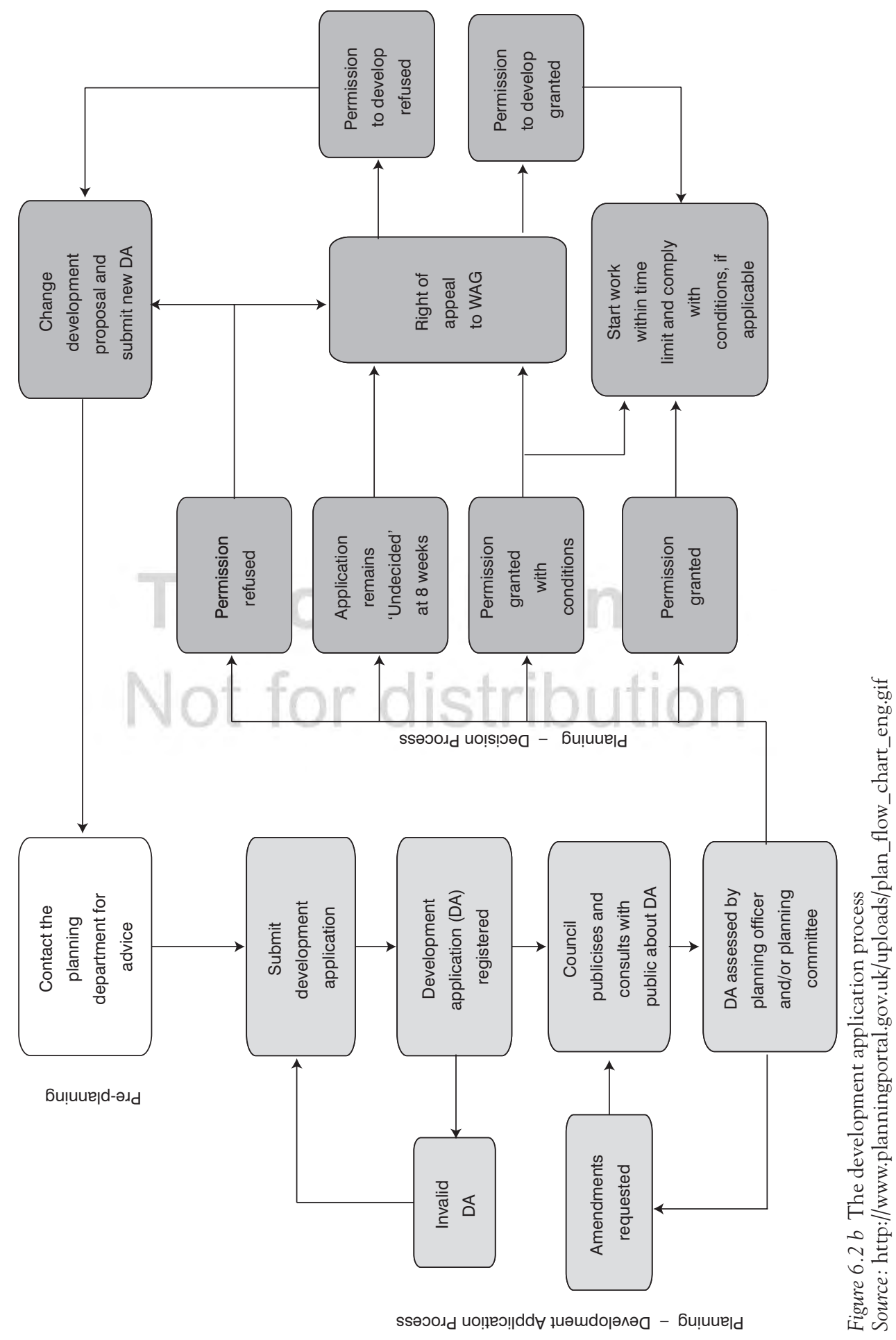


Finally, the nature of the documentation required will have an impact on the level of sustainability incorporated. It is here that EU requirements may increase the burden on developers and their teams by the need for an Environmental Impact or indeed full Sustainability Assessment to be undertaken. Even if these are not required, a scheme of any local significance will now almost certainly require a design and access statement which will need to address matters such as the use of sustainable materials, flood risk prevention, travel plans, biodiversity measures and on-site energy generation. Whilst this may increase the initial costs of preparing the application it does ensure that constructive consideration is now routinely built into the planning process by all stakeholders; this should lead to more thoughtful and longer-lived developments which respect their local context and the wider environment.

In summary, the UK process has now embedded sustainability through both national policy and local implementation. Whilst there are still undoubtedly flaws in the systems, it bodes well moving forward. The biggest risk is yet another change in legislative direction before this has been able to bed in and the results become visible in the town and cityscape.

\subsubsection{The United States}

The planning system in the US has many similarities with the Australian system. Like the Australian system, the federal government has limited responsibilities related to urban planning, although in both countries the federal government is able to influence the state and local planning efforts indirectly through legislation (e.g. environmental impact laws) and funding stipulations. Individual states are responsible for managing the landuse planning system. States develop enabling legislation and policy guidelines to establish local planning parameters (Gurran 2011); however, the ability for states to intervene in local planning policy decisions varies from state to state as a result of differing state constitution provisions for state intervention in local policy matters. This means that any drive to use planning as an mechanism to drive sustainable development is not deeply embedded.

For states mandating the adoption of a comprehensive plan at the local level, required elements most often include land use and transportation elements, but may also include: housing, utilities, natural and cultural resources, economic development or other elements deemed important by the legislators. Examples of this state requirement include the Oregon Department of Land Conservation and Development's Key Elements Of The Comprehensive Plan document and the Wisconsin comprehensive planning and smart growth law (1999 Wisconsin Act 9 as amended by Act 148). Ohm (2010) breaks down each element of the Wisconsin law in detail. Where states do not mandate the adoption of comprehensive plans, local jurisdictions have more freedom in establishing development plans and controls, although they must still conform to relevant state and federal legislation. As a result of this planning system, there are vast differences in land-use planning and policy approaches across the US not only at the state level, but even more so at the local level. A typical development application process is illustrated in Figure 6.4. Note there will be some variation in implementation as a result of the varying local planning and policy approaches in different local communities. Note the community consultation process in the US is more extensive than in either the Australian or UK planning systems. Participatory planning plays a major role in the American planning system and can be very influential in the development approval process; indeed the very notion of participatory planning owes its origin to the work of Arnstein whose seminal work promoted the now well known 'ladder 


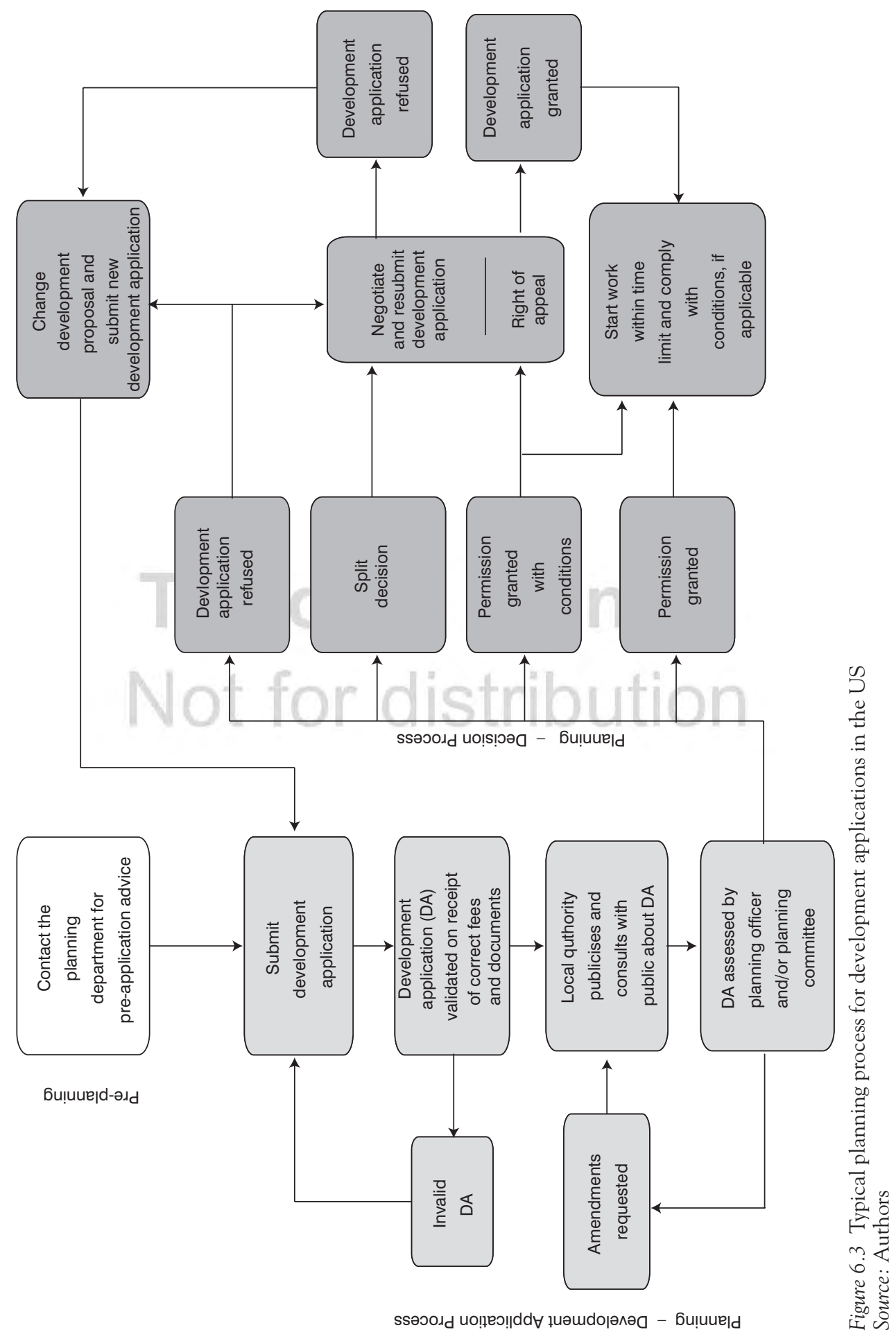




\section{Pernille H. Christensen and Sarah L. Sayce}

of participation' (Arnstein 1969). For this reason it is advised that property developers engaged with the participatory planning process begin by building 'buy-in' among the various stakeholder groups which will be influenced by their project; better still they engage them actively as participants in the design journey.

A key driver of the planning process in the United States is that the planning process 'links an upfront public policy making process to a wide variety of follow-on implementation process' (Beckner 2010: 6). This process was laid out in its modern form in the early twentieth century but has undergone significant changes since its inception. The Standard State Zoning Enabling Act was published in 1924 as a model to facilitate orderly land-use development, provide certainty for property investors and protect individual property rights. As a result of the strong emphasis on zoning in American planning practice, the courts have had a significant role in the development of the US planning process. In 1926, in Village of Euclid, Ohio vs. Amber Realty Company (272 US 365), the US Supreme Court upheld zoning as a valid form of regulation and police power. This case had a strong influence on the Euclidean Zoning practices being used in many communities throughout the US today. The 1930s saw land-use zoning, building setbacks and public housing initiatives used to address issues related to the spread of diseases in urban tenement housing. The 1950s brought a series of initiatives for urban renewal which were followed by a series of new programmes focusing on environmental issues in the 1960s and 1970s (e.g. water pollution control, airquality improvement, wetlands protection, environmental impacts). Current efforts by the American Planning Association (APA), the International Council for Local Environmental Initiatives (ICLEI) and the US Green Building Council include policy guides for 'Smart Growth and 'Complete Streets' strategies to assist states and local communities in their efforts to achieve more compact, environmentally friendly and sustainable development. Beckner (2010) offers an excellent discussion of emerging trends in planning sustainable communities in the US. Below, the development plans and controls impacting sustainable property development in the United States are highlighted.

- National-level planning policies: Among the national-level policies influencing sustainable development is the National Environmental Policy Act (NEPA) 1969, which established a broad national framework for protecting the environment. NEPA requires federal agencies to consider environmental values in their decision-making process and assures that all branches of government consider the environmental impact of any and all major federal actions. Environmental impact statement (EIS) requirements are also detailed by NEPA. In addition, the Comprehensive Environmental Response, Compensation, and Liability Act (CERCLA, or as commonly known, Superfund) specifically addresses the development of brownfield sites. Enacted by Congress on 11 December 1980, CERLA includes long-term site remediation and short-term removal of hazardous materials. CERCLA collected over US $\$ 1.6$ billion in taxes from petroleum and chemical industries that went into a trust fund for cleaning up abandoned or uncontrolled hazardous waste sites. For property developers interested in infrastructure projects, the Air Quality Act of 1990 essentially merged comprehensive transportation and land-use planning at the metropolitan level with the regional airquality planning process. All federally assisted transportation improvements (highway and transit systems) in metropolitan areas were required to attain particular air-quality standards.

- Local-level planning policies: A growing number of states require comprehensive plans, which aim to establish guidelines for future growth in a given community. It is a formal 
document including goals and policies, maps and guidelines that may be either advisory in nature or adopted into law by the local authority. The comprehensive plan acts as a policy guide for the future community on decisions related to infrastructure systems as well as the quality, location and amount of property development for a 10-20 year time frame. Zoning Ordinances are the most widely used land-use regulation instrument and include written requirements and standards related to the use of land. In recent years, there have been a number of innovative approaches to zoning which increase flexibility for developers and in many cases also promote sustainable property development. Examples of this include: cluster zoning, incentive zoning, inclusionary zoning, and flexible zoning.

\subsection{Development incentives}

In the US, there have been several series of cutbacks from the federal government which limit the ability for communities to use federal aid dollars to incentivise property development projects. This scenario is similar to the challenges faced by communities in many other countries as well. In order to continue supporting projects, local communities have had to increasingly rely on local incentive schemes such as: tax increment financing, special assessment districts, tax abatements, land swaps, lease/purchase agreements, capital improvements, and value creating trade-offs based on zoning bonuses. In exchange for absorbing some of the development risk, the local community often takes a direct financial stake in the property development project through participatory leases and/or profit-sharing agreements. Often the profit-sharing revenues offer minimum profit to the local community during the initial years, however, the profit-sharing structure offers the city other nonfinancial benefits. In part, they offer political protection to city councils vulnerable to charges that they are giving away too much because 'a financial agreement to share returns is perceived as a sign that the city is acting responsibly and effectively' (Miles et al. 1997).

There are essentially two methods by which regulatory and financial incentives can promote the sustainable property development in their communities, carrots and sticks. 'Carrots' include incentives for 'doing the right thing'; some might say these positive incentives are offsetting externalities that could otherwise be considered negative externalities by the developer to create a balanced score sheet. Example of positive incentives include rebates and grants (e.g. Photovoltaic Rebate Program and the Greenhouse Gas Abatement Grant in Australia), carbon credit trading (allowed by the Kyoto Protocol), and streamlining the development application process among others. Another option is by allowing alternative compliance tracks to prescriptive development plans and controls. One example is Queensland's Sustainable Planning Act 2009, which allows developers to choose between a traditional 'code assessable' track or an 'impact assessable' option that offers a potentially more flexible compliance track whereby more interpretive criteria must be demonstrated.

'Sticks' promote sustainable property development through regulatory means; some might say they are a means of preventing negative externalities. Examples include local building codes, taxes and levies (e.g. landfill levies), mandated renewable energy certificates (e.g. the Australian Renewable Energy Act 2000) and slower processing times for development applications. Clark (2003) offers a thorough discussion of the various incentive programmes available in Australia. A report by the American Institute of Architects (AIA) and the National Association of Counties (NACo) (AIA and NACo 2012) outlines state and local 


\section{Pernille H. Christensen and Sarah L. Sayce}

government green building incentives and a discussion of how to select which incentives will best meet the needs of both local governments and property developers.

In an interview with Denis Hayes, President and CEO of the Bullitt Foundation, he notes that one of the primary concerns for property developers is time. Most property developers do not have the benefit of the holding period to recoup their costs for developing a sustainable manner. Although market demands may drive sustainable property development in some markets, this is not the case for all urban areas let alone rural areas. As such, local planning authorities looking to influence developers to develop property in a sustainable manner need to consider the planning aspects which they control that might impact a developer's bottom line. Hayes worked with the city of Seattle to develop a Living Building and Deep Green Pilot ordinance to promote sustainable property development. A key aspect of the city of Seattle approach includes the Priority Green Facilitated Pilot programme which shortens review time. As time equals money for most developers, being able to process the development application quicker is a significant incentive for many developers in Seattle. A more detailed discussion of financial incentives can be found in Chapter 5 .

\subsection{Conclusion}

Understanding the purpose and application of development planning: policy, controls and incentives enables property developers to understand specific planning local systems within which they aim to achieve sustainable property development. As noted in this chapter, there are different levels at which planning policies and strategies are developed; these include national, state, regional, local, precinct and site level. At all of these levels, planning systems ultimately reflect the strategic goals for property development and aim to prevent negative impacts from development on their communities.

Taxation and incentives, such as relaxed planning zones, can be used to encourage positive outcomes consistent with their strategic plans and local land-use plans. Ultimately, all property development initiates interaction with the planning system upon submission of the development application for a particular project. All property development must work within the confines of the relevant planning controls and regulations at all levels of government, but may find that developing property in a sustainable manner can help streamline the process and reduce the review; indeed in some jurisdictions the principles of sustainability are now being systematically and progressively embedded within policy and control practice. The examples of the varying structures of planning systems in Australia, the UK and the US exemplify the difference in approaches property developers must take to make their projects a reality. As already noted, the trend in Australia is towards greater standardisation and codification of routine development types, while still providing greater flexibility for more significant proposals; in the UK a centralised system is being combined with a loosening of controls at the local level. This dichotomy at times raises other challenges and concerns. The US employs more prescriptive approaches through the use of zoning and development standards, although new strategies such as Smart Codes, smart growth and form-based codes are gaining traction.

Brain argues that policymakers strive to 'achieve an end with means that are never neutral in themselves. In the context of the urban landscape, every design and planning decision is a value proposition, and a proposition that has to do with social and political relationships' (Brain 2005: 233). Brain's contention, is that value propositions and value positions cannot be ignored when considering the relationship between the means and ends; the means being the instruments and the ends discussed in this chapter being sustainable 
property development. If we truly aim to develop property in a more sustainable manner we must begin to assert these values in the property development process. The planning stage is an ideal opportunity to capture the value propositions and positions in a manner that has the opportunity to influence the development plans and controls; this is being government led in countries such as the UK; elsewhere the state is less interventionist in promoting sustainability. Only by doing so, can we begin to make real progress beyond the few developers who either truly believe in 'doing the right thing and leading the charge' or they believe in the economic proposition and see an opportunity for added value in developing sustainably.

\section{References}

Amati, M. (ed.) (2012) Urban Green Belts in the Twenty-first Century, Farnham: Ashgate.

Amati, M., and Yokohari, M. (2006) Temporal changes and local variations in the functions of London's green belt, Landscape and Urban Planning 75(1): 125-142.

Allmendinger, P.,and Haughton, G. (2014) Post-political regimes in English planning, Planning Against the Political: Democratic Deficits in European Territorial Governance 29.

AIA and NACo (American Institute of Architects and the National Association of Counties) (2012) Local Leaders in Sustainability: green building incentive trends - strengthening communities, building green economies. Retrieved 28 April 282014 from http://www.aia.org/aiaucmp/ groups/aia/documents/pdf/aiab093472.pdf.

Arnstein, S.R. (1969) A ladder of citizen participation. Journal of the American Institute of Planners 35(4): 216-224.

Barker, Kate (2006) Barker Review of Land Use Planning: Final Report - Recommendations, London: The Stationery Office.

Beckner, Chrisanne (ed.) (2010) Planning infrastructure to sustain America: next-generation concepts to guide community, design and infrastructure professions. American Society of Civil Engineers (ASCE) Practice, Education and Research for Sustainable Infrastructure (PERSI) Task Committee on Planning for Sustainable Infrastructure. Retrieved 14 May 2014 from http://www.asce.org/ uploadedFiles/Sustainability___New/Resources/PLANNING\%20INFRASTRUCTURE\%20 TO\%20SUSTAIN\%20AMERICA\%20100915-2.pdf.

Betts, C. (2011) The National Planning Policy Framework: Eighth Report of Session 2010-12, Vol. 1: Report, Together with Formal Minutes, Oral and Written Evidence, Vol. 1, London: The Stationery Office.

Bosselmann, Klaus (1995). When Two Worlds Collide: Society and Ecology. Auckland: RSVP Publishers.

Bosselmann, Klaus (2013) The Principle of Sustainability: Transforming Law and Governance, Farnham: Ashgate.

Brain, David (2005) From good neighbourhoods to sustainable cities: social science and the social agenda of the New Urbanism, International Regional Science Review, 28(2): 217-238.

Brearley, J.S. (2012) What's wrong with planning? - and is it about to be fixed? - a cri de coeur, Journal of Planning and Environment Law (5): 534.

Cambridge Centre for Housing and Planning Research (2014) The Nature of Planning Constraints: Report to the House of Commons Communities and Local Government Committee, Cambridge: University of Cambridge.

Christensen, Pernille. (2012) Key strategies of sustainable real estate decision-making in the United States: a Delphi study of the stakeholders. Dissertation, Clemson University.

Clark, D. (2003) Incentives for sustainable buildings in Australia - a designer's perspective, Sinclair Knight Merz Technical Paper, Melbourne, Vic: Sinclair Knight.

CLG (Communities and Local Government) (2012) The National Planning Policy Framework. Retrieved from https://www.gov.uk/government/publications/national-planning-policy-framework--2. 


\section{Pernille H. Christensen and Sarah L. Sayce}

Department of Infrastructure and Transport (DIT) (2011) Our cities, our future: a national urban policy for productive, sustainable and liveable future. Retrieved 1 May 2014 from http://www. infrastructure.gov.au/infrastructure/pab/urbanpolicy/.

Duxbury, R. (2012) Telling and Duxbury's Planning Law and Procedure, Oxford: Oxford University Press.

Gurran, N. (2011) Australian Urban Land Use Planning: Principles, Systems and Practice, second edn, Sydney: Sydney University Press.

Hall, A.C. (2008) The form-based development plan: bridging the gap between theory and practice in urban morphology, Urban Morphology 12(2): 77-95.

Hall, T. (2011) Proactive engagement in urban design - the case of Chelmsford, in S. Tiesdell and D. Adams (eds), Real Estate Issues: Urban Design in the Real Estate Development Process, Oxford: Wiley-Blackwell, pp. 74-91.

Hayes, Denis. (2014) Personal Interview by author, 8 May.

Holman, N. and Rydin, Y. (2013) What can social capital tell us about planning under localism?, Local Government Studies 39(1): 71-88.

ISOCARP (International Society of City and Regional Planners) (2001) International Manual Planning Practice, fourth edn. The Netherlands: ISOCARP, UNESCO, Ministry of Housing, Spatial Planning and the Environment.

Killian, J. and Pretty, D. (2008) Planning Applications: A Faster and More Responsive System, Final Report, London: DCLG.

NSW (New South Wales Department of Planning \& Environment (DPE)) (2014a) Legislation. Retrieved 21 May 32014 from http://www.planning.nsw.gov.au/en-au/policyandlegislation/ legislationandplanninginstruments.aspx

New South Wales (NSW) Department of Planning \& Environment (DPE) (2014b) Standard Instrument Local Environmental Plan (LEP) Program. Retreived 21 May 32014 from http://www. planning.nsw.gov.au/en-us/planningyourlocalarea/standardinstrument.aspx

Ohm, Brian W. (2010) Required elements of the local comprehensive plan. Retrieved 12 May 2014 from http://oconto.uwex.edu/files/2010/08/required_elements_of_a_local_comprehensive_plan. pdf

Ohm, Brian W. (2000) Reforming land planning legislation at the dawn of the 21st century: the emerging influence of smart growth and liveable communities, The Urban Lawyer, 32(2): 181-210.

Oregon Department of Land Conservation and Development (2000) Planning for Natural Hazards: Key Elements of a Comprehensive Plan in Oregon's Statewide Land Use Planning Program. Retrieved 3 May 2014 from http://www.oregon.gov/LCD/HAZ/docs/landslides/02_elements.pdf.

Paterson, E. (2012) Urban design and the national planning policy framework for England, Urban Design International 17(2): 144-155.

Rydin, Y. (2011) The Purpose of Planning: Creating Sustainable Towns and Cities, Bristol: Policy Press.

Schilling, J. and Logan, J. (2008) Greening the rust belt: a green infrastructure model for right sizing America's shrinking cities, Journal of the American Planning Association 74(4): 451-466.

Sepp, K. (2011) The Estonian Green Belt, Tallinn: Estonian University of Life Sciences.

Simons, L., Slob, A., Holswilder, H., and Tukker, A. (2001) A Fourth Generation: New strategies call for new eco-indicators, Environmental Quality Management 11(2): 51-61.

Tiesdell, Steve and Adams, David (eds) Real Estate Issues: Urban Design in the Real Estate Development Process, Oxford: Wiley-Blackwell, 2011. Retrieved from site.ebrary.com/lib/utslibrary/ Doc?id=10510477\&ppg=311.

Zhao, P. (2011) Managing urban growth in a transforming China: evidence from Beijing, Land Use Policy 28(1): 96-109. 